\title{
Trigeminal trophic syndrome after infection with herpes zoster
}

\author{
Sónia Raquel Mendes 조 , Miguel Gouveia, José Carlos Cardoso
}

Dermatology Department, Coimbra University Hospital, Coimbra, Portugal

Correspondence to Dr Sónia Raquel Mendes; soniaraquel23@gmail.com

Accepted 24 August 2021

\section{DESCRIPTION}

We report the case of a 86-year-old woman, with an infection in V1-V2 herpes zoster in the right hemiface, evolving for 5 days, who subsequently developed ulcerations on nasal ala and temporal region (figure 1).

Herpes zoster infection was treated with valacyclovir $1000 \mathrm{mg}$ three times a day, for 7 days.

The lesions began as small erosions, with rapid growth.

She also presented two homolateral periorbital ulcers.

Ten days after the appearance of herpes zoster lesions, she presented ulceration with destruction of the right nasal ala causing significant loss of tissue with semilunar morphology, associated with erythema and oedema of the surrounding area (figure 2). The tip of the nose and left nasal ala were spared.

She mentioned neuropathic pain and paraesthesias; concomitantly, she reported loss of sensitivity of these territories.

At this point, the patient started treatment with oral gabapentin with progressive dose titration until $300 \mathrm{mg}$ three times per day for 4 months, after which it was gradually reduced to $300 \mathrm{mg}$ one time per day, with good response.

After 15 days, she mentioned some itching and still reported neuropathic pain, although with some improvement after starting treatment with gabapentin.

After 5 months, the patient showed complete healing of the ulceration of the right nasal ala and

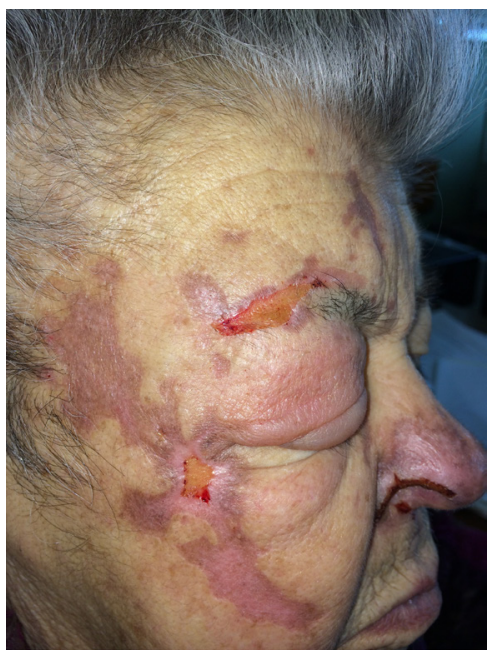

Figure 1 Ulcerations on nasal ala and temporal region in the right hemiface.

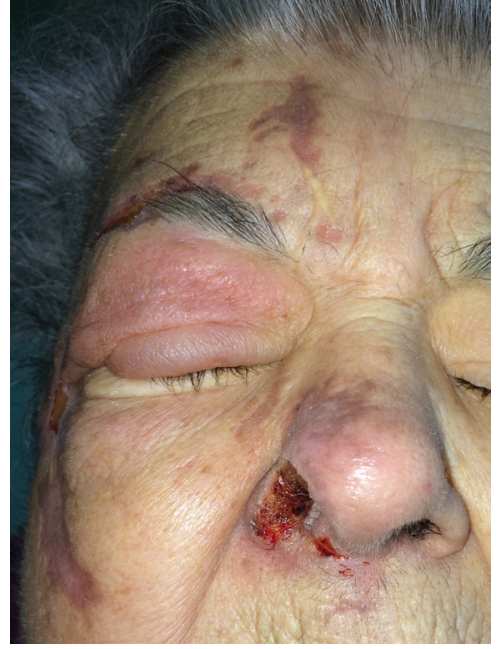

Figure 2 Ulceration with destruction of the right nasal ala; the tip of the nose and left nasal ala were spared.

did not show local recurrence or other skin lesions after 4 years of follow-up.

Trigeminal trophic syndrome (TTS), which was first described in 1933 by Loveman and McKenzie, is a rare cause of facial ulcer and its diagnosis requires exclusion of all other causes of localised ulcers on the face. ${ }^{1-3}$ It is more common among women. ${ }^{12}$ It may be related to injury to the trigeminal ganglion (Gasserian ganglion) in the central or peripheral sensory portions. ${ }^{1-5}$ It is defined by the classic triad of paraesthesia (in the affected hemiface), anaesthesia (in the injured trigeminal sensory branches) and increasing ulcer in the nasal ala. ${ }^{1-5}$ Nasal ala is the most common location, although the scalp, frontal, auricular, malar, mandibular and temporal areas, as well as the upper lip, palate and cornea may also be affected. ${ }^{124}$ TTS is commonly associated with trigeminal ganglion ablation, surgical removal of the trigeminal nerve and strokes. ${ }^{124}$ Rare causes include tumours, trauma, infections (herpes, syphilis, leprosy), anterior inferior cerebellar artery infarction and syringobulbia. ${ }^{124}$ Differential diagnosis includes neoplasms (basal cell and squamous cell carcinomas, lymphoma), infections (herpes zoster, herpes simplex, syphilis, mycobacteria, dimorphic fungi, leishmaniasis), systemic vasculitis (Wegener's granulomatosis, giant-cell arteritis, temporal arteritis) and pyoderma gangrenosum. ${ }^{1-5}$ Treatment is difficult; apart from counselling the patients to avoid self-manipulation of the wound, occlusive dressings may be applied over the affected area to reduce trauma. ${ }^{1}$ Medications such as diazepam, amitriptyline, chlorpromazine and 
carbamazepine are used to reduce paraesthesias. ${ }^{12}$ Transcutaneous electrical stimulation, ipsilateral cervical sympathectomy, stellate ganglionectomy, radiotherapy and iontophoresis with nerve blockade have been tried in treatment-resistant cases. ${ }^{12}$ In cases of extensive nasal ulcer, prostheses and surgical reconstruction with skin grafting followed by pulsed radiofrequency may be indicated to improve paraesthesias. ${ }^{12}$

\section{Learning points}

The diagnosis of trigeminal trophic syndrome (TTS) can be difficult and requires exclusion of all other causes of localised ulcers on the face and requires a sound clinicopathological correlation; herpes zoster infection is an uncommon cause of TTS.

- Treatment is difficult and includes pharmacological and nonpharmacological approach.

- Due to the altered sensation, patients tend to persistently manipulate the affected areas thus perpetuating the external triggering trauma.
Contributors SRM (first author): acquisition and analysis of data, planning conducting, conception and design of the article, as well as revision and final approval. MG: acquisition of data and final approval. JCC: acquisition of data, revision and final approval.

Funding The authors have not declared a specific grant for this research from any funding agency in the public, commercial or not-for-profit sectors.

Competing interests None declared.

Patient consent for publication Obtained.

Provenance and peer review Not commissioned; externally peer reviewed.

\section{ORCID iD}

Sónia Raquel Mendes http://orcid.org/0000-0002-9070-6634

\section{REFERENCES}

1 Karadan U, Manappallil RG, Janardhanan A, et al. Trigeminal trophic syndrome following anterior inferior cerebellar artery infarction. BMJ Case Rep 2018;2018:bcr2018225278.

2 Neoh CY, Tan AWH. Trigeminal trophic syndrome: an unusual cause of a non-healing cheek ulcer. Singapore Med J 2007;48:e22-4.

3 Ferrara G, Argenziano G, Cicarelli G, et al. Post-apopletic trigeminal trophic syndrome. J Eur Acad Dermatol Venereol 2001;15:153-5.

4 Kautz 0, Bruckner-Tuderman L, Müller ML, et al. Trigeminal trophic syndrome with extensive ulceration following herpes zoster. Eur I Dermatol 2009;19:061-3.

5 Monrad SU, Terrell JE, Aronoff DM. The trigeminal trophic syndrome: an unusual cause of nasal ulceration. J Am Acad Dermatol 2004;50:949-52.

Copyright 2021 BMJ Publishing Group. All rights reserved. For permission to reuse any of this content visit

https://www.bmj.com/company/products-services/rights-and-licensing/permissions/

BMJ Case Report Fellows may re-use this article for personal use and teaching without any further permission.

Become a Fellow of BMJ Case Reports today and you can:

- Submit as many cases as you like

- Enjoy fast sympathetic peer review and rapid publication of accepted articles

- Access all the published articles

- Re-use any of the published material for personal use and teaching without further permission

\section{Customer Service}

If you have any further queries about your subscription, please contact our customer services team on +44 (0) 2071111105 or via email at support@bmj.com.

Visit casereports.bmj.com for more articles like this and to become a Fellow 